\title{
INSECTICIDAL AND REPLLENET ACTIVITIES OF CITRUS PEEL OILS AGAINST MEALYBUG ICERYA SEYCHELLARUM (WESTWOD)
}

\author{
EL-BADAWY, S.S.
}

\author{
Plant Protection Research Institute, ARC, Dokki, Giza, Egypt.
}

(Manuscript received 20 April 2015)

\begin{abstract}
$\mathrm{E}$ ssential oils extracted from peels of five citrus fruit species namely: navel and baladi oranges (Citrus sinensis L.), grapefruit (Citrus paradisi Macfad), lemon (Citrus limon L.) and mandarin (Citrus reticulata Blanco), belonging to family Rutaceae were tested for their insecticidal and repellent activities at three different concentrations (1000, 5000, $10000 \mathrm{ppm}$ ) against nymphs and adults of mealybug Icerya seychellarum . Also, formulated compounds, navel orange oil $(1 \%)$, limonene $(1 \%)$ and two recommended reference products ( $2 \%$ insecticidal soap and $1.5 \%$ Super Misrona), were bioassayed against mealybug $I$. seychellarum. The results revealed that, the oil of navel orange achieved the highest toxicity against nymphs and adults of mealybug $I$. seychellarum with $\mathrm{LC}_{50}$ values of $(406.97,370.04 \mathrm{ppm})$, respectively, while, oil of mandarin recorded the lowest toxicity $\left(L_{50}=4148.80\right.$, $3435.99 \mathrm{ppm})$, respectively. Navel orange oil (1\%) was more potent than limonene (1\%) alone, while, limonene $(1 \%)$ was more potent than the two reference products. Citrus species oils exhibited high repellency rate against the nymphs of $I$. seychellarum at the used concentrations. The highest repellency was achieved by navel orange oil, while, the lowest one was recorded with mandarin oil. The essential oils of five citrus species were isolated by hydrodistillation and the analysis of essential oil by GC/MS revealed the presence of 32 peaks, approximately all peaks were identified. The chemical composition showed that limonene was the main constituent in the five citrus oils and ranged from 67.50 to $91.20 \%$. No phytotoxic symptoms were observed on Mango leaves treated by the citrus essential oils (Orange and baladi) and limonene. The results of the present study suggested that, orange oils (Navel and baladi) and pure limonene used as safe, potential natural products for control of $I$. seychellarum on Mango trees and may be used as alternatives to the reference products after application of these results in the semifield and field experiments.
\end{abstract}

Keywords: Citrus fruit species, essential oils, Icerya seychellarum, repellent and insecticidal activities.

\section{INTRODUCTION}

Citrus and mango trees are considered of the most popular and economic fruit trees in Egypt. They occupy the first and third ranks from the commercial point of view. Citrus and mango trees are liable to be infested with many serious pests 
during their growth stages including Icerya seychellarum (Westwod) (Hemiptera: Monophlebidae) (Assem, 1990).

In general, control of citrus mealybugs around the world relies heavily on use of insecticides and mineral oils. However, continuous and heavy use of these synthetic pesticides has created serious problems such as environmental pollution, toxicity to non-target organisms (parasitoids and predators), pest resistance and pesticide residues (Mohan and Fields, 2002). Therefore, there is an urgent need to develop new, convenient and safer alternatives to synthetic pesticides. Essential oils and their major constituents, attracted research attention in recent years as potential alternatives to synthetic insecticides (Aslan et al., 2004).

The genus Citrus includes several important fruits such as oranges, mandarins, lime, lemons and grapefruits. The essential oils of some citrus species have been reported to have insecticidal properties against insect pests (Elhag, 2000). The major active component of citrus oil is limonene and using $1 \%$ limonene mixture was safe for most plants and provided good control of mealybugs and scale insects. This mixture controlled $99 \%$ of whiteflies, whereas the full-strength mixture controlled from 69 to $100 \%$ of mealybugs and scale insects (Hollingsworth, 2005).

The present study aimed to investigate the efficacy of five Egyptian citrus peel essential oils against nymphs and adults of mealybug $I$. seychellarum. Also, extraction, determination and chemical analysis of essential oils and limonene were studied.

\section{MATERIALS AND METHODS}

\section{Tested citrus species:}

The experimental five citrus species, navel orange (Citrus sinensis L.), baladi orange (Citrus sinensis L.), grapefruit (Citrus paradisi Macfad), lemon (Citrus limon L.) and mandarin (Citrus reticulata Blanco), belonging to family Rutaceae were selected for this study. These citrus species were purchased from the local market.

\section{Insects source:}

Insect culture for laboratory experiments were obtained from a private mango orchard (called Fisher orchard) located at El-Saff, Giza, Egypt. Samples of Fagrikelan trees which highly infested with $I$. sechellryum were collected randomly from each of the four cardinal directions (East, West, North and South) of the middle crown parts. Leaves were packed in paper bags and transferred to the laboratory and they were maintained at laboratory temperature about $25 \pm 1^{\circ} \mathrm{C}$ and $65 \pm 1 \%$ relative humidity. In the laboratory, mealybug $I$. sechellryum was identified by department of mealybug and scale insects-Plant Protection Researches Institute-Agriculture Researches Center. 


\section{Preparation of formulated compounds:}

The pure limonene was purchased from Sigma-Aldrich Chemical Co. and the two reference products $\{$ Mineral oil Super Misrona (95\% paraffin oil) and Insecticidal Soap ( $49 \%$ potassium salts of fatty acids)\}, were purchased from Miser petroleum Co. Concentrations of $1 \%$ from orange essential oil and $1 \%$ from pure limonene were prepared. The two reference products Mineral oil and Insecticidal Soap were used with recommended doses (1.5\% Super Misrona oil and $2 \%$ Insecticidal soap) in the Egyptian fields and being diluted with distilled water.

\section{Extraction of citrus oils and limonene}

\subsection{Extraction of citrus oils:}

Citrus oils were extracted by Cavalcanti et al. (2004). The peels of the fresh five species of citrus fruits were dried at $30 \pm 5^{\circ} \mathrm{C}$, the dried peels were grounded into fine powder. The essential oil was extracted from the fresh and dried peels ( $200 \mathrm{~g}$ weight of each sample in $400 \mathrm{ml}$ of distilled water) by hydrodistillation using a modified Clevenger type apparatus for $4 \mathrm{~h}$. The distilled was extracted with diethyl ether after saturation with sodium chloride. The extracted oils were dried over anhydrous sodium sulfate, then packed in dark container, and stored at $4^{\circ} \mathrm{C}$ until used for GC-MS analysis and bioassays.

\subsection{Extraction and gravimetric determination of limonene}

Limonene was extracted and determined according to Cavalcanti et al. (2004). Samples of five species peels (the outer coloured layer of peels) were carefully collected using the grater. The amount of peels produced was weighed and record it. Then each sample was cut down to a mass of approximately $0.1 \mathrm{~g}$. Add the peels and $200 \mathrm{ml}$ of distilled water to a $500 \mathrm{ml}$ flask and setup for distillation. Collect distillate until no further oily liquid appears to co-distill with the water. The oil layer will be on the surface. Separate the limonene from the aqueous distillate using a separating funnel. The percentage yield of D-Limonene calculated by this equation:

$\%$ yield $=$ mass of limonene $/$ mass of orange peel $\times 10$

\section{Chemical analysis of essential oil:}

\subsection{Chemical analysis of citrus peel oils constituents:}

The extracted citrus oils were subjected to GC/MS analysis using Shimadzu GC/MS-QP-5050A. Column: DB5, 30m, 0.53mm ID, 1.5 $\mu \mathrm{m}$ film. Carrier gas: Helium (flow rate $1.2 \mathrm{ml} / \mathrm{min}$.). Ionization mode: (70ev). The injection volume was $0.5 \mu \mathrm{l}$ (split ratio of $1: 100$ ), Temperature program: $50^{\circ} \mathrm{C}$ (static for $2 \mathrm{~min}$ ) with gradually increasing (a rate of $4^{\circ} \mathrm{C} / \mathrm{min}$ ) up to $200^{\circ} \mathrm{C}$ then $\left(10^{\circ} \mathrm{C} / \mathrm{min}\right.$ ) to $280^{\circ} \mathrm{C}$. The detector temperature was $290^{\circ} \mathrm{C}$, while, the injector temperature was $250^{\circ} \mathrm{C}$. 


\subsection{Identification of the chemical constituents:}

Qualitative identification of the essential oil was achieved by library searched data base Willey 229 LIB as well as by comparing their retention indices and mass fragmentation patterns with those of the available references and with published data, (Adams, 2007). The percentage composition of components of the volatile was determined by computerized peak area measurements.

\section{Toxicity bioassays:}

A series of laboratory bioassays were conducted to determine the bioactivity of five citrus oils (Navel orange, baladi orange, grapefruit, lemon and mandarin) and formulated compounds: navel orange oil (1\%), pure limonene $(1 \%)$, insecticidal soap (2\%) and Super Misrona oil (1.5\%) against nymphs and adults of $I$. seychellarum.

\subsection{Spray toxicity assay:}

The toxicity bioassay was conducted to evaluate toxicity of citrus oils of navel orange, baladi orange, grapefruit, lemon and mandarin to nymphs and adults of $I$. seychellarum at three different concentrations (1000, 5000, 10000ppm). In spray toxicity assay, Fagrikelan mango leaves containing slowly moving crawlers and immobile crawlers of late instar nymphs and adults mealybugs were placed into plastic Petri dishes (10cm dia $\times 2 \mathrm{~cm} \mathrm{ht}$ ). After solvent evaporation (hexane) for each citrus oil peel, ten infested leaves (each bearing not less than 10 nymphs and adults) were sprayed with $1 \mathrm{ml}$ for five seconds with each citrus oil and other formulated compounds \{Navel orange oil (1\%), limonene (1\%), insecticidal soap (2\%) and Super Misrona oil $(1.5 \%)\}$, then, kept at room temperature. Control insects were sprayed with hexane for citrus oils, with water for insecticidal soap (2\%) and Super Misrona oil (1.5\%) and with $2 \%$ tween-20 emulsifier for navel orange oil (1\%) and limonene (1\%). Five replicates were used and the experiment was repeated for three times and mortality was recorded after 48 hrs.

\subsection{Repellency assay (Filter paper test):}

The repellency (or) attractiveness of the five citrus oils against $I$. seychellarum nymphs was determined as described by (Wang et al., 2009). The citrus oils were diluted in hexane to three concentrations $(1000,5000,10000$ ppm). Filter paper $(6 \mathrm{~cm}$ in diameter) was cut in half and $150 \mu$ of each concentration was applied separately to half of the filter paper as uniformly as possible with a micropipette. The other half (control) was treated with $150 \mu \mathrm{l}$ of absolute hexane. Both the treated half and the control half were then air dried to evaporate the solvent completely. Nymphs of $I$. seychellarum were collected from Fagrikelan mango leaves before the experiment and were starved for 6 hrs. Ten nymphs were placed in the center of the dish, $4 \mathrm{~cm}$ away from both the treated half and the control half. Dish was covered and maintained at room temperature. After 24 hours, number of nymphs on the treated half and the 
control half was counted. Five replicates were used and the experiment was repeated for three times. The percent repellency was calculated using the formula:

$$
\mathrm{PR}(\%)=[(\mathrm{NC}-\mathrm{NT}) /(\mathrm{NC}+\mathrm{NT})] \times 100
$$

where: $\mathrm{NC}$ is the number of nymphs presents in the negative control half,

$\mathrm{NT}$ is the number of nymphs presents in the treated half.

\section{Phytotoxicity test:}

The sprayed leaves were checked for the presence of phytotoxicity by using $1 \%$ navel and baladi orange oils, $1 \%$ solution of limonene, Super Misrona oil (1.5\%) and insecticidal soap (2\%) according to (Karamaouna et al., 2013). Phytotoxic effects were observed (discoloration, necrosis of the leaf, loss of leaf sheen and wilting). Phytotoxicity data were recorded after 24,48 and $72 \mathrm{~h}$. The evaluation of phytotoxicity severity was assessed as leaf surface percentage with symptoms, i.e., brown necrotic spots or discoloration over a wider area of the leaf blade: none (0-1\%), slight (1$25 \%)$, medium (25-50\%), high (> 50\%).

\section{Statistical analysis}

The percentage of the mortality was recorded and the mortality was corrected with Abbot formula (Abbott, 1925). LdP-line program was used to determinate LC $_{50}$ values. Data of all experiments were evaluated statistically using ANOVA and means compared using Duncan's Multiple Range Test at $\mathrm{P}<0.05$ ). All statistical analyses were done using the software package Costat.

\section{RESULTS AND DISCUSSION}

\section{Yield and chemical analysis of citrus peel essential oils.}

\subsection{Yields of essential oil.}

The essential oils yields of five fresh and dried citrus peels ( $C$. sinensis, baladi orange, $C$. paradisi, $C$. limon and $C$. reticulata) were shown in Fig. (1). A significant variation among the yield of essential oil from citrus species was noted. The yields of essential oils of citrus species were significantly affected by drying treatment. Among the citrus species tested, navel orange exhibited the highest oil yield $(3.10,4.30 \%)$ followed by baladi orange $(2.50,3.50 \%)$, mandarin $(1.00,1.40 \%)$ and lemon $(0.60$, $1.20 \%)$, respectively, while, grapefruit showed the smallest value of $(0.50,0.80 \%)$, In general, dried citrus peels had higher oil yield than fresh samples.

Our results are in agreement with the findings of Kamal et al. (2011), who showed that, the yields of essential oils from fresh, ambient and oven-dried peels of three citrus species, $C$. reticulata, $C$. sinensis and $C$. paradisi were significantly $(p<0.05)$ varied and ranged from $0.30-0.50,0.24-1.07$ and $0.20-0.40 \mathrm{~g} / 100 \mathrm{~g}$ peels, respectively, according to drying treatments and species. They also, investigated, oven-dried citrus peels had higher oil yield followed by the ambient-dried and fresh 
samples. Adebisi (2014), reported that, the essential oil yields of fresh and dried peels of orange ( $C$. sinensis) and grapefruit (C. paradisi) ranged between 1.01 and $2.30 \%$ , respectively, and the fresh samples generally had low yield when compared with dry samples, this may be due to the high water content of the materials.

\subsection{Yields of limonene from gravimetric method and GC-MS analysis.}

The limonene yields of the gravimetric method (fresh peels) and GC/MS analysis essential oils (dried peels) of five citrus species were given in Fig. (2). The results revealed that, the yields of limonene widely varied depending on citrus species and drying. The production yields of limonene from the gravimetric method were lower than that from GC/MS analysis with all citrus species tested. The highest yields of limonene in the gravimetric method and GC/MS analysis were recorded with navel orange $(3.30,4.13 \mathrm{ml} / 100 \mathrm{~g}$ dried peels), respectively. While, the lowest yields of the both determination methods were obtained from grapefruit peel $(0.59,0.76)$, respectively. The yields of the others three citrus species (Baladi orange, lemon and mandarin) were $(2.90,3.31),(1.10,1.86)$ and $(0.67,0.90)$, respectively. These observations are in agreement with the findings of Lopresto et al. (2014), who, showed that the yield of D-limonene of lemon peel was significantly $(p<0.05)$ affected by drying treatments, the highest amount of D-limonene was obtained from oven-dried sample of lemon peel (3.48\%) with respect to fresh peel (1.29\%).

\subsection{Chemical analysis of constituents of citrus oils.}

The chemical composition of the essential oils of five citrus fruits peels are presented in Table (1). The essential oil analysis by GC/MS revealed that, the presence of 32 peaks, all peaks were identified, representing 99.97, 98.45, 99.07, 99.22 and $98.04 \%$ of the essential oils of the five citrus species, navel and baladi oranges ( $C$. sinensis), C. paradisi, $C$. limon and $C$. reticulata, respectively. The major constituents of these essential oils mainly belonged to two groups: monoterpene and oxygenated monoterpenes, while, the minor constituents belonged to: sesquiterpene and oxygenated sesquiterpene hydrocarbons. Oxygenated monoterpenes hydrocarbons with contribution of 4.50, 4.91, 9.05, 6.51 and $9.05 \%$ constituted the second major portion of the essential oils after monoterpenes hydrocarbons (94.95, 93.00, 87.53, 92.10 and 86.31\%) from peel oils. Sesquiterpene and oxygenated sesquiterpnes hydrocarbons were present at very low levels in the oils of the five citrus species.

The chemical analysis of the citrus oils showed limonene as the main constituent (91.10, 90.20, 82.60, 70.10 and $67.50 \%$ ) for navel orange, baladi orange, grapefruit, lemon and mandarin oils, respectively. The monoterpene hydrocarbons $a$ pinene, sabinene, $\beta$-pinene, linalool oxide, linalool, limonene oxide, a-terpineol, decanal and citral are present in all studied citrus oils. The qualitative and quantitative 
compositions of the essential oils of dried citrus peels showed that, the most abundant ingredients of the citrus peels oils beside to limonene, were linalool $(1.78 \%)$ and $a$ pinene $(1.63 \%)$ in navel orange oil, while, eugenol (1.56\%) and $a$-pinene (1.52\%) were the major components of baladi orange. The grapefruit oil contained linalool oxide (2.19\%), $\beta$-myrcene (2.16\%), a-terpineol (1.50\%) and citral $(1.20 \%)$. The main components of lemon oil were $\beta$-pinene $(9.10 \%)$, $\mathrm{y}$-terpinene $(5.00 \%), a$ pinene $(2.10 \%)$ and citral $(1.63 \%)$. The mandarin oil contained p-cymene $(5.11 \%)$ in high percentage, $\mathrm{y}$-terpinene $(3.90 \%), \beta$-myrcene $(3.30 \%)$ and $a$-pinene $(1.98 \%)$. Among other monoterpenes, a-thujene, a-fenchene, 3-carene, a-phellandrene, aterpinene, $\beta$-ocimene, a-terpinolene, octanal, citronellal, citronellol, geranial, neral, neryl acetates and nerol were present in appreciable levels.

Our results of the chemical composition of citrus peel oils are in agreement with many other studies (Mansour et al., 2004, Ahmad et al., 2006 and Asekun et al., 2007). All these studies showed that, limonene was the main component with high variation in all citrus peel oils and also, there are considerable variations in the other constituents of the chemical composition of each citrus oil with respect to varieties and drying conditions. Such variation in chemical composition (Limonene content and other constituents) in citrus peel oils may be related to the time of harvesting, the degree of freshness, genetic makeup and the size of the fruit. Also, geographical location, fruit variety, and method of extraction (Ahmad et al., 2006).

\section{Toxicity bioassays:}

\subsection{Spray toxicity of citrus essential oils:}

The obtained citrus essential oils species, which, including navel orange, baladi orange, grapefruit, lemon and mandarin in this study was mainly conducted to investigate a relationship between the oil constituents specially limonene and their potency towards nymphs and adults of $I$. seychellarum. The results of toxicity assays (spray toxicity) as represented in Table (2), showed that, essential oil of all citrus species peel exhibited toxicity rate with concentration dependent. Citrus peel essential oils of navel orange achieved significantly the highest mortality percentages against nymphs and adults at the different concentrations (1000, 5000, $10000 \mathrm{ppm}$ ). The highest toxicity rate against nymphs and adults was recorded for navel orange essential oils $(95.67 \pm 0.68 \%$ and $95.21 \pm 0.19 \%)$, respectively, at the maximum concentration $10000 \mathrm{ppm}$, followed by baladi orange $(93.92 \pm 0.07 \%$ and $94.17 \pm$ $0.17 \%)$, respectively. The percentages of mortality achieved by grapefruit and lemon essential oils were $(81.58 \pm 0.13 \%, 84.24 \pm 0.15 \%)$ and $(80.51 \pm 0.18 \%, 82.37 \pm 0.08 \%)$, respectively, while, the lowest mortality was obtained with mandarin oil $(70.14 \pm 0.32 \%)$ and $(75.28 \pm 0.08 \%)$, respectively at the same concentration. Generally, all five citrus oils species were toxic to nymphs and adults of $I$. 
seychellarum at the medium 5000ppm and the maximum concentration $10000 \mathrm{ppm}$. There were significant differences in mortality between control and treated variants $(P<0.05)$.

From the data presented in Table (2), it could be demonstrated that navel orange peel oil was the most potent nymphicidal and adultscidal effect $\left(\mathrm{LC}_{50}=406.97\right.$, $370.04 \mathrm{ppm})$, followed by baladi orange oil $(927.07,870.75 \mathrm{ppm})$. While, mandarin oil was the lowest potent $\left(\mathrm{LC}_{50}=4148.80,3435.99 \mathrm{ppm}\right)$. The $\mathrm{LC}_{50}$ values of grapefruit and lemon were $(2180.90,1980.56 \mathrm{ppm})$ and $(2411.50,2346.27 \mathrm{ppm})$. The toxicity assays indicate the order of nymphcidal and adultscidal activities in citrus peels essential oils as: Navel orange followed by Baladi orange, Grapefruit, Lemon and Mandarin. The $\mathrm{LC}_{50}$ values of the five citrus oils, ranged from 406.97 to $4148.80 \mathrm{ppm}$ for nymphs and from 370.04 to $3435.99 \mathrm{ppm}$ for adults depending on the toxicity of essential oils and the mealybug life stage. The $\mathrm{LC}_{50}$ values for each essential oil did not reveal any significant differences between nymphs and adults. These findings are confirmed by Karamaouna et al. (2013), who showed that the citrus peel essential oils of lemon ( $C$. limon) and orange ( $C$. sinensis) were the most toxic of all the tested essential oils against $3^{\text {rd }}$ instar nymphs and female adults of the vine mealybug, Planococcus ficus (Signoret).

The results of toxicity of formulated toxicants tested, represented in Figure (3), revealed that, navel orange oil (1\%) exhibited the highest potency $(88.28 \pm 0.225 \%$ mortality) against $I$. seychellarum followed by $1 \%$ limonene $(81.22 \pm 0.199 \%)$, then $2 \%$ insecticidal soap $(70.88 \pm 0.459 \%)$, while, the lowest value was recorded with $1.5 \%$ Super Misrona oil $(59.71 \pm 0.164)$. The toxicity order of navel orange peel oil $(1 \%)$ compared with the other compounds tested as : Navel orange oil followed by Limonene, Insecticidal soap and Super Masrona oil. This meaning that, a high toxic effect of the tested navel orange oil and limonene compared to the reference products (Super Misrona oil and Insecticidal soap). These findings are confirmed by Karamaouna et al. (2013), who showed that, the $\mathrm{LC}_{50}$ values of citrus (C. sinensis and $C$. limon) oils ranged from 2.7 to $8.1 \mathrm{mg} / \mathrm{ml}$ depending on the essential oil and the mealybug life stage. These $\mathrm{LC}_{50}$ values were significantly lower than the $\mathrm{LC}_{50}$ of the reference paraffin oil in the respective $P$. ficus life stages.

Regarding to potency of citrus oils against nymphs and adults of $I$. seychellarum, the data presented in Table (2) indicate that the potency of the tested oils was related to limonene content of that oils. Navel and baladi orange oils of 91.10 $\%$ and 90.10 limonene content (Table 1 ), respectively, showed the highest toxicity $\left(\mathrm{LC}_{50}=406.97,370.04\right.$ and $\left.927.07,870.75 \mathrm{ppm}\right)$, respectively, while, mandarin oil of $67.50 \%$ limonene content exhibited the lowest toxicity $\left(\mathrm{LC}_{50}=4148.8,3435.99 \mathrm{ppm}\right)$. 
Our results are confirmed by El-Badawy (2014), who showed that the repellent and toxic effects of Dabsha mango leaves essential oil on $I$. seychellarum could be related to the high content of limonene. Also, these results are in agreement with these obtained by Ibrahim et al. (2001) who stated that the monoterpene limonene showed deterrent and insecticide properties, which might used in pest control in organic agriculture. The best limonene mixture (1\% limonene, $0.75 \%$ emulsifier APSA-80 and $0.1 \%$ surfactant Silwet) controlled from 69 to $100 \%$ of mealybugs and scale insects, depending on the species, insect stage, and application method (Hollingsworth, 2005). Spray applications of limonene in $1 \%$ aqueous solution resulted in $44 \%$ mortality of $3^{\text {rd }}$ and $4^{\text {th }}$ instar nymphs of Planococcus citri. This mortality was equal to the mortality caused by a reference insecticidal soap and significantly higher than the mortality caused by a reference horticultural spray oil (paraffin oil) and mortality of green scales Coccus viridis (Green) on potted gardenia plants averaged 95,89 , and $88 \%$ on plants sprayed with limonene, insecticidal soap, or horticultural oil, respectively (Hollingsworth, 2005).

On the other hand, the toxicities of grapefruit, lemon and mandarin were lower than that of navel and baladi orange, could be mainly attributed to their lower content of limonene and high contents of a-pinene and $\beta$-pinene. Papachristos et al. ( 2009) found that, sweet oranges and bitter orange essential oils exhibited similar toxicity against Ceratitis capitata larvae, which was significantly higher than that the lemon essential oil, because the presence of a-pinene and $\beta$-pinene in lemon essential oil was considered to account for the lower toxicity of lemon essential oils in relation to that of sweet oranges and bitter orange,

\subsection{Repellency study:}

Essential oils of five citrus species were evaluated for their repellent activity against $I$. seychellarum nymphs. The essential oils from five citrus species exhibited good repellent activities against $I$. seychellarum nymphs at the given concentrations in Table (3). The repellent rate of navel orange oil was clearly higher than other citrus oils at all concentrations. Data in Table (3) also, showed that, navel orange essential oil possess the highest repellent activity $(59.17 \pm 0.404,73.27 \pm 0.332$ and $92.60 \pm 0.135 \%)$ against $I$. seychellarum at the tested concentrations $(1000,5000$, $10000 \mathrm{ppm})$ respectively followed by lemon oil $(55.68 \pm 0.189,71.96 \pm 0.151$ and $86.88 \pm 0.012 \%)$, respectively, then, baladi orange oil $(52.95 \pm 0.072,61.27 \pm 0.216$ and $81.58 \pm 0.040 \%)$, respectively, finally, grapefruit oil $(46.55 \pm 0.104,58.82 \pm 0.569$ and $70.51 \pm 0.076 \%)$, respectively, while, the lowest repellent activity was recorded with mandarin oil $(42.55 \pm 0.628,49.27 \pm 0.328$ and $61.22 \pm 0.506 \%)$, respectively.

The decreasing order of repellency of the five citrus oils to nymphs was navel orange followed by lemon, baladi orange, grapefruit and mandarin. These results 
suggested that, navel orange and lemon oils have positive repellent effect on $I$. seychellarum nymphs. The high repellency rates of navel orange could be mainly attributed to their high content of limonene. Although, lemon had less limonene content than grapefruit, but, higher in repellency rate than grapefruit, this may be attributed to the high contents of $\beta$-pinene $(9.10 \%)$ and $\gamma$-terpinene $(5.00 \%)$ in lemon. Many studies showed that, essential oils of citrus species have repellent activities against various insects of different families. Limonene is found to be repellent against several pest insects (Ibrahim et al., 2001). Citrus essential oils have been found to participate in resistance of citrus fruits against infestation of Mediterranean fruit fly, C. capitata (Papachristos et al., 2009).

The minor components relatively like a-thujene, a-fenchene, 3-carene, aphellandrene, a-terpinene, a-terpinolene, citronellal, citronellol, geranial, neral, neryl acetates and nerol may be play an important role in repellent and insecticidal activities of citrus species essential oil against I. seychellarum. Consequently, the higher insecticidal or repellent potencies of the tested oils may refer to synergistic, antagonistic or additive effects between limonene and the other minor constituents in those oils. (Mansour et al., 1996) showed that, the difference in the potency of essential oils may refer to the quantity of the active component(s) rather than the quality. Also, Mansour et al. (2003) mentioned that, different constituents in a botanical extract may interact with each others, leading to synergistic or antagonistic effects. This confirmed our results and supports our conclusion.

\section{Phytotoxicity of essential oils on mango leaves:}

No phytotoxic symptoms were observed on Fagrikelan Mango leaves treated with navel orange oil $(1 \%)$, baladi orange oil $(1 \%)$ and pure limonene (1\%). Super Misrona oil caused slight phytotoxicity, whereas, insecticidal soap (IS) caused medium phytotoxicity in most of the concentrations applied, Table (4). In general, the citrus essential oils did not cause phytotoxicity on Fagrikelan Mango leaves.

These findings are agreement with (Karamaouna et al., 2013), they showed that, no phytotoxic symptoms were observed on grape leaves treated with the citrus oils (Orange and lemon). Also, the paraffin oil caused slight phytotoxicity. Selectivity data of $2 \%$ limonene in aqueous solution showed little phytotoxic effects (Hollingsworth, 2005). In addition, limonene has been shown to be phytotoxic to strawberries at concentrations exceeding $3 \%$ and cabbage and carrot seedlings at concentrations higher than 9\% (Ibrahim et al., 2001). 


\section{CONCLUSION}

1- All citrus oils specially navel and baladi oranges achieved high insecticidal and repellent activities against $I$. seychellarum and no phytotoxic effect on Mango leaves, so, they can be used as an effective natural alternatives to mineral oil Super Misrona and insecticidal soap.

2- Overall results indicated that the toxic and repellence effects of citrus oils on I. seychellarum could be related to the high content of limonene.

3- The yield and content of the chemical components of the tested citrus oils varied significantly with respect to species used.

4- The peel essential oils from the five citrus species rich in limonene with maximum amount detected in navel and baladi oranges followed by grapefruit, then lemon and finally, mandarin.

5- Orange citrus oil (included limonene) was more toxic than limonene alone against $I$. seychellarum. Therefore, we concluded that, the direct use of citrus peel oils (high limonene content) in insect control purposes is less expensive and time consuming than separating the compound from the oil.

6- There are synergistic or antagonistic effects between limonene and the other minor constituents in the citrus oils.

\section{RECOMMENDATION}

It is recommended to expand such laboratory experiments to to semifield and field conditions and determine the efficacy of orange citrus essential oils against $I$. seychellarum and other mealybug and scale insects.

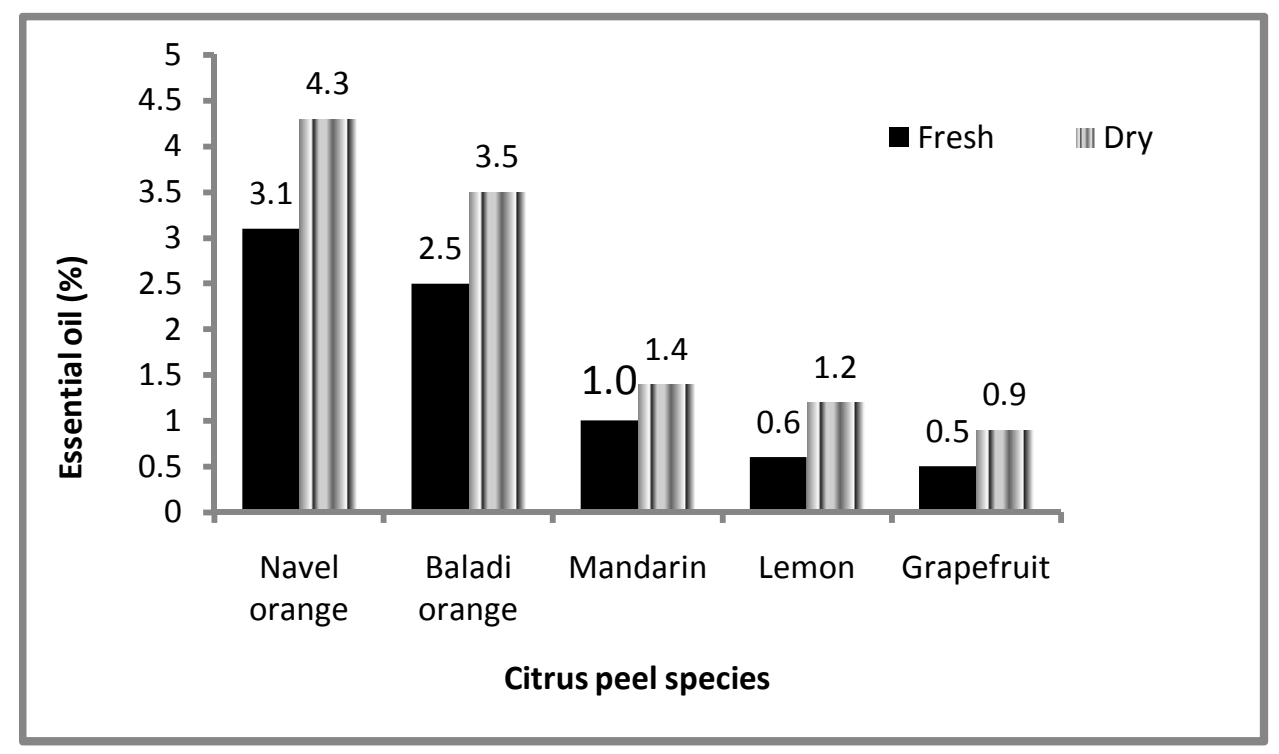

Fig. 1. Yields of essential oils from fresh and dried peels of five various citrus species. 


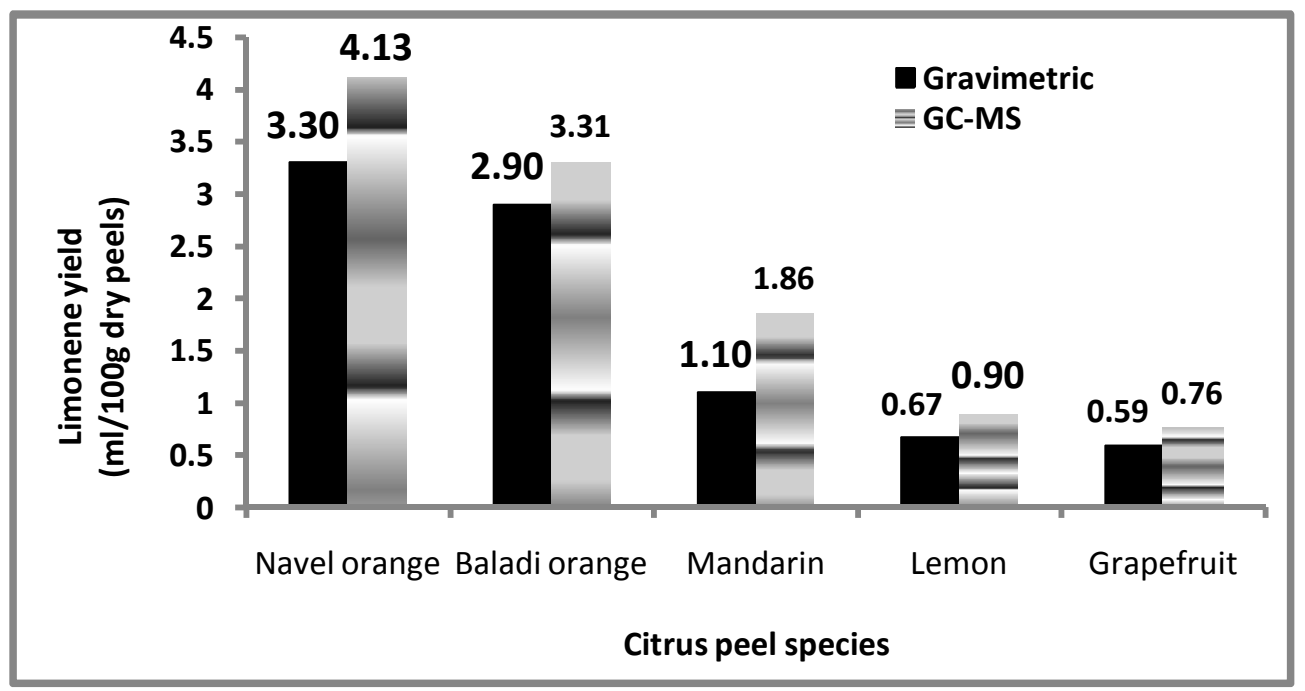

Fig. 2. Variation of Limonene yields in five citrus peel oils with gravimetric and GC-MS determination methods.

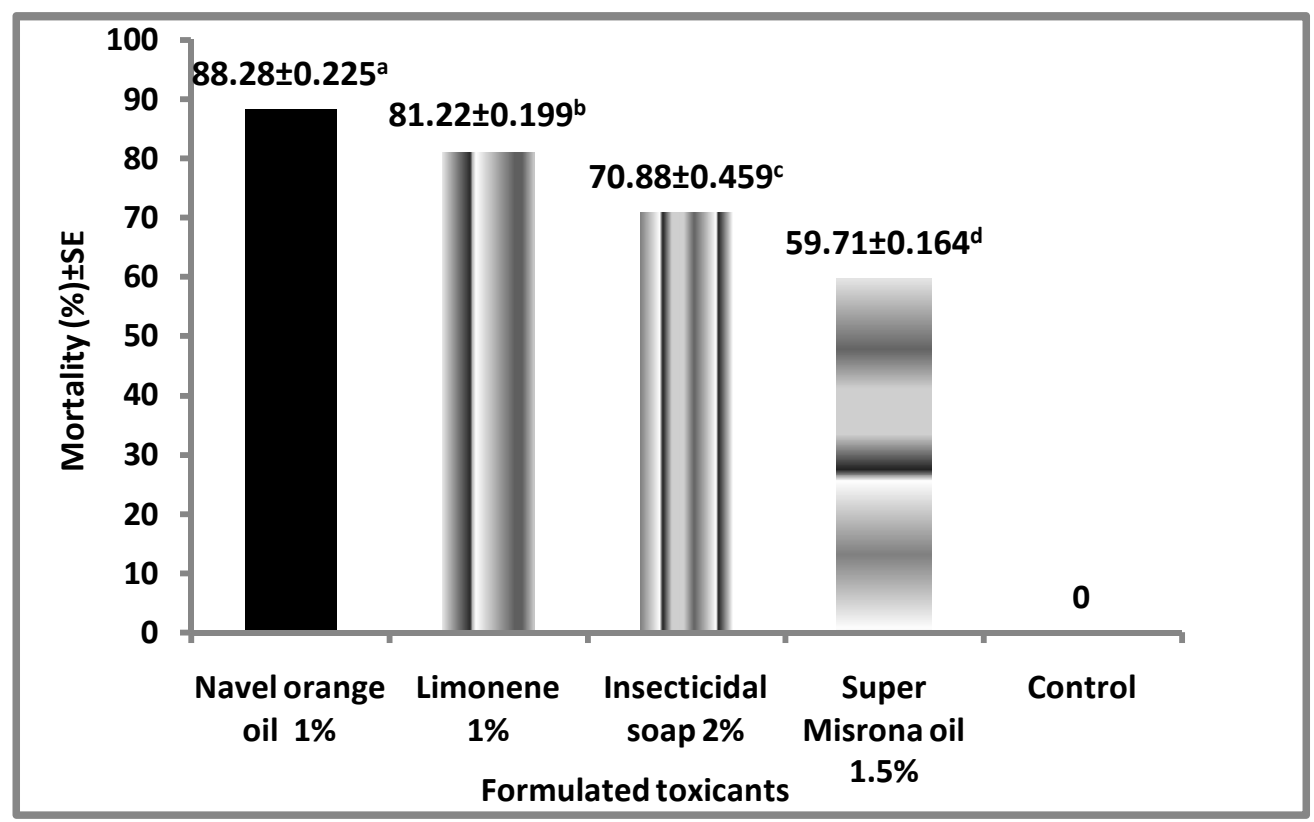

Fig. 3. Mortality percentages of different formulated toxicants against $I$. seychellarum. 
Table 1. Chemical composition of essential oils from peels of five citrus species.

\begin{tabular}{|c|c|c|c|c|c|c|c|}
\hline \multirow{2}{*}{ No. } & \multirow{2}{*}{ Components } & \multirow[b]{2}{*}{$\mathrm{RT}$ (min.) } & \multicolumn{4}{|c|}{ Ratio (\%) } & \multirow[b]{2}{*}{ C5 } \\
\hline & & & $\mathrm{C} 1$ & $\mathrm{C} 2$ & $\mathrm{C} 3$ & C4 & \\
\hline 1 & a-Thujene & 6.25 & - & - & - & 0.59 & 0.28 \\
\hline 2 & a-pinene & 7.22 & 1.63 & 1.52 & 1.05 & 2.10 & 1.98 \\
\hline 3 & a-Fenchene & 8.35 & 0.27 & - & - & - & 0.73 \\
\hline 4 & Sabinene & 9.54 & 0.20 & 0.23 & 0.52 & 1.10 & 0.98 \\
\hline 5 & $\beta$-Pinene & 9.75 & 0.10 & 0.23 & 0.17 & 9.10 & 0.91 \\
\hline 6 & $\beta$-myrcene & 10.57 & 0.23 & 0.40 & 2.16 & 1.25 & 3.30 \\
\hline 7 & Octanal & 11.56 & 0.26 & - & - & - & 1.90 \\
\hline 8 & 3-Carene & 11.82 & 0.26 & - & - & - & 0.32 \\
\hline 9 & a- Phellandrene & 12.05 & 0.27 & - & - & - & - \\
\hline 10 & a-Terpinene & 12.30 & - & 0.10 & - & 1.10 & 0.23 \\
\hline 11 & p- Cymene & 12.43 & - & - & - & 1.16 & 5.11 \\
\hline 12 & Limonene & 12.83 & 91.10 & 90.10 & 82.6 & 70.10 & 67.50 \\
\hline 13 & $\beta$-Ocimene & 13.20 & 0.20 & 0.30 & - & - & 0.45 \\
\hline 14 & $\mathrm{Y}$-Terpinene & 14.55 & 0.12 & - & 0.94 & 5.00 & 3.90 \\
\hline 15 & a -Terpinolene & 15.52 & 0.07 & 0.12 & 0.09 & 0.60 & 0.62 \\
\hline 16 & Linalool oxide & 15,73 & 0.20 & 0.32 & 2.19 & 0.19 & 0.60 \\
\hline 17 & Linalool & 16.74 & 1.78 & 0.16 & 1.33 & 0.83 & 1.92 \\
\hline 18 & Limonene oxide & 17.56 & 0.15 & 0.70 & 1.10 & 0.20 & 1.00 \\
\hline 19 & a-Terpineol & 20.36 & 0.39 & 1.03 & 1.50 & 0.50 & 0.45 \\
\hline 20 & Decanal & 20.77 & 0.38 & 0.45 & 0.09 & 1.09 & 1.00 \\
\hline 21 & Citronellal & 21.05 & 0.28 & - & 0.64 & - & 1.29 \\
\hline 22 & Citral & 21.70 & 0.19 & 0.35 & 1.20 & 1.63 & 0.60 \\
\hline 23 & Citronellol & 22.10 & 0,40 & & 1.00 & & - \\
\hline 24 & Geranil & 22.81 & - & 0.34 & - & 0.78 & 0.29 \\
\hline 25 & Eugenol & 23.75 & 0.29 & 1.56 & - & - & - \\
\hline 26 & Neral & 25.74 & 0.26 & - & - & 0.50 & - \\
\hline 27 & Neryl acetate & 26.10 & 0.13 & - & - & 0.29 & - \\
\hline 28 & Nerol & 27.45 & 0.19 & - & - & 0.50 & - \\
\hline 29 & $\beta$-Caryophyllene & 42.45 & 0.25 & - & 0.23 & 0.23 & 0.69 \\
\hline 30 & Valencene & 43.97 & 0.20 & - & 1.10 & - & - \\
\hline 31 & Z-Nerolidol & 49.30 & 0.57 & 0.54 & 0.45 & - & 1.54 \\
\hline \multirow[t]{6}{*}{32} & Farnesol & 53.34 & - & - & 0.71 & 0.38 & 0.45 \\
\hline & \multicolumn{2}{|c|}{ Monoterpene Hydrocarbons } & 94.45 & 93.00 & 87.53 & 92.10 & 86.31 \\
\hline & \multicolumn{2}{|c|}{$\begin{array}{l}\text { Oxygenated Monoterpene Hydrocarbon } \\
\text { s }\end{array}$} & 4.50 & 4.91 & 9.05 & 6.51 & 9.05 \\
\hline & \multicolumn{2}{|c|}{ Sesquiterpene Hydrocarbons } & 0.45 & - & 1.33 & 0.23 & 0.69 \\
\hline & \multicolumn{2}{|c|}{$\begin{array}{l}\text { Oxygenated Sesquiterpene } \\
\text { Hydrocarbons }\end{array}$} & 0.57 & 0.54 & 1.16 & 0.38 & 1.99 \\
\hline & \multicolumn{2}{|l|}{ Total } & 99.97 & 98.45 & 99.07 & 99.22 & 98.04 \\
\hline
\end{tabular}

$\mathrm{C} 1=$ Navel orange

C4= Lemon

$\mathrm{RT}=$ Retention time.
$\mathrm{C} 2=$ Baladi orange

$\mathrm{C} 5=$ Mandarin
$\mathrm{C} 3=$ Grapefruit 
Table 2. Toxic effect (Spray assay) of five citrus species peels essential oils against I. seychellarum nymphs and adults at different concentrations.

\begin{tabular}{|c|c|c|c|c|c|c|c|c|}
\hline \multicolumn{9}{|c|}{ Corrected mortality(\%) \pm SE } \\
\hline Conc. (ppm) & 1000 & 5000 & 10000 & \multirow[b]{2}{*}{$\mathrm{LC}_{50}(\mathrm{ppm})$} & 1000 & 5000 & 10000 & \multirow[b]{2}{*}{$\mathrm{LC}_{50}(\mathrm{ppm})$} \\
\hline $\begin{array}{c}\text { Citrus peel } \\
\text { oils }\end{array}$ & \multicolumn{3}{|l|}{ Nymphs } & & \multicolumn{3}{|l|}{ Adults } & \\
\hline Navel orange & $67.53 \pm 0.36^{a}$ & $83.52 \pm 0.50^{\mathrm{a}}$ & $95.67 \pm 0.68^{\mathrm{a}}$ & 406.97 & $68.50 \pm 0.29^{\mathrm{a}}$ & $85.44 \pm 0.22^{\mathrm{a}}$ & $95.21 \pm 0.19^{a}$ & 370.04 \\
\hline Baladi orange & $54.43 \pm 0.59^{b}$ & $71.14 \pm 0.15^{\mathrm{b}}$ & $93.92 \pm 0.07^{\mathrm{b}}$ & 927.07 & $55.41 \pm 0.21^{\mathrm{b}}$ & $73.24 \pm 0.02^{\mathrm{b}}$ & $94.17 \pm 0.17^{b}$ & 870.75 \\
\hline Grapefruit & $39.91 \pm 0.09^{c}$ & $53.60 \pm 0.10^{c}$ & $81.58 \pm 0.13^{c}$ & 2180.90 & $41.97 \pm 0.07^{c}$ & $59.47 \pm 0.21^{c}$ & $84.24 \pm 0.15^{c}$ & 1980.56 \\
\hline Lemon & $36.55 \pm 0.13^{d}$ & $54.82 \pm 0.03^{\mathrm{d}}$ & $80.51 \pm 0.18^{\mathrm{d}}$ & 2411.50 & $36.40 \pm 0.16^{d}$ & $56.50 \pm 0.26^{d}$ & $82.37 \pm 0.08^{\mathrm{d}}$ & 2346.27 \\
\hline Mandarin & $29.75 \pm 0.22^{\mathrm{e}}$ & $51.93 \pm 0.13^{\mathrm{e}}$ & $70.14 \pm 0.32^{\mathrm{e}}$ & 4148.80 & $30.85 \pm 0.09^{\mathrm{e}}$ & $52.84 \pm 0.12^{\mathrm{e}}$ & $75.28 \pm 0.08^{\mathrm{e}}$ & 3435.99 \\
\hline Control & 0.00 & 0.00 & 0.00 & & 0.00 & 0.00 & 0.00 & \\
\hline $\operatorname{LSD}_{0.05}$ & $0.6098 * * *$ & $0.4115^{* * *}$ & $0.6147 * * *$ & & $0.5717^{* * *}$ & $0.6049 * * *$ & $0.5020 * * *$ & \\
\hline
\end{tabular}

Values (means \pm SE) followed by similar letter within the same column do not differ significantly $(P<0.05)$. 
Table 3. Repellency percentages of five citrus species peels essential oils against $I$. seychellarum nymphs at different concentrations.

\begin{tabular}{|c|c|c|c|}
\hline \multirow{2}{*}{ Citrus peel oils } & \multicolumn{3}{|c|}{ Repellency \pm SE (\%) } \\
\cline { 2 - 4 } & \multicolumn{3}{|c|}{ Conc. (ppm) } \\
\cline { 2 - 4 } & 1000 & 5000 & 10000 \\
\hline \multirow{2}{*}{ Navel orange } & $59.17 \pm 0.404^{\mathrm{a}}$ & $73.54 \pm 0.332^{\mathrm{a}}$ & $92.60 \pm 0.135^{\mathrm{a}}$ \\
\hline \multirow{2}{*}{ Baladi orange } & $55.68 \pm 0.189^{\mathrm{b}}$ & $71.96 \pm 0.151^{\mathrm{b}}$ & $86.88 \pm 0.012^{\mathrm{b}}$ \\
\hline Lemon & $52.95 \pm 0.072^{\mathrm{c}}$ & $61.27 \pm 0.216^{\mathrm{c}}$ & $81.58 \pm 0.040^{\mathrm{c}}$ \\
\hline Grapefruit & $46.55 \pm 0.104^{\mathrm{d}}$ & $58.82 \pm 0.569^{\mathrm{d}}$ & $70.51 \pm 0.076^{\mathrm{d}}$ \\
\hline Mandarin & $42.55 \pm 0.628^{\mathrm{e}}$ & $49.27 \pm 0.328^{\mathrm{e}}$ & $61.22 \pm 0.506^{\mathrm{e}}$ \\
\hline LSD 0.05 & $0.7978^{* * *}$ & $1.4322^{* * *}$ & $1.0239^{*} * *$ \\
\hline
\end{tabular}

Values (means $\pm S E$ ) followed by similar letter within the same column do not differ significantly $(P<0.05)$.

Table 4. Phytotoxicity of some formulated toxicant on Fagrikelan Mango leaves.

\begin{tabular}{|c|l|c|c|c|}
\hline \multirow{2}{*}{ Tested toxicant } & \multirow{2}{*}{ Symptoms } & \multicolumn{2}{|c|}{ Phytotoxicity (\%) } \\
\cline { 3 - 5 } & & \multicolumn{2}{|c|}{ Conc. (ppm) } \\
\cline { 3 - 5 } & & 1000 & 5000 & 10000 \\
\hline Navel orange (1\%) & No & 0 & 0 & 1 \\
\hline Baladi orange (1\%) & No & 0 & 0 & 1 \\
\hline Limonene (1\%) & No & 0 & 0 & 5 \\
\hline Super Misrona (1.5\%) & Medium discoloration and little spots & 15 & 20 & 25 \\
\hline Insecticidal soap (2\%) & Brown necrotic spots and discoloration & 20 & 30 & 50 \\
\hline
\end{tabular}




\section{REFERENCES}

1. Abbott, W. S. 1925. A method of computing the effectiveness of an insecticide. J. Econ. Entomol., 18: 265-267.

2. Adams, P.R. 2007. Identification of essential oil components by gas chromatography/ mass spectromety, $4^{\text {th }}$. Ed. Allured Publishing Corp. Carol Stream, Illinois, USA.

3. Adebisi, O. 2014. Comparative study of essential oil composition of fresh and dry peel and seed of Citrus sinensis (L.) Osbeck Var Shamuti and Citrus paradisi Macfadyen Var Marsh. J. Sci. 16 (2): 211-217.

4. Ahmad, M. M., S. Rehman, Z. Iqbal, F.M. Anjum and J. I. Sultan 2006. Genetic variability to essential oil composition in four citrus fruit species. Pak. J. Bot., 38:319-324.

5. Asekun, O. T., D. S. Grierson and A. J. Afolayan 2007. Effects of drying methods on the quality and quantity of the essential oil of Mentha longifolia L. subsp. Capensis. Food Chem., 101: 995-998.

6. Aslan, I., H. Ozbek, O. Calmasur and F. Sahin 2004. Toxicity of essential vapours to two greenhouse pests, Tetranychus urticae Koch and Bemisia tabaci Genn. Indust. Crops Prod., 19: 167-173.

7. Assem, S.M. 1990. Survey and biological studies on some insects attacking certain ornamental plants. Ph.D. Thesis, Fac. Agric., Cairo Univ., Cairo, Egypt, 202p.

8. Cavalcanti, E. S. B., S. M. Morais, M. A. A. Lima and E. W. P. Santana. 2004. Larvicidal activity of essential oils from Brazilian plants against Aedes aegypti L. Mem Inst Oswaldo Cruz 99:541-544.

9. El-Badawy, S. S. 2014. Interpretation phenomenon of infestation susceptibility of some mango cultivars with mealybug Icerya seychellarum (Westwod) (Hemiptera: Monophlebidae). Egypt J. Agric. Res., 92 (4): 1235-1252.

10. Elhag, E. A. 2000. Deterrent effect of some botanical products on oviposition of the cowpea bruchide callosobruchus maculatus (F.) (Coleoptera:Bruchid). Intern. J. Pest Manag., 46 (2): 109-113.

11. Hollingsworth, R. G. 2005. Limonene, a citrus extract, for control of mealybugs and scale insects. Ecotoxicol., 98:772-779.

12. Ibrahim, M. A., P. Kainulainen, A. Aflatuni, K. Tilikkala and J. K. Holopainen 2001. Insecticidal, repellent, antimicrobial activity and phytotoxicity of essential oils: With special reference to limonene and its suitability for control of insect pests. Agric. Food Sci. Finland, 10: 243-259. 
13. Kamal, G. M., F. Anwar, A. I. Hussain, N. Sarri and M. Y. Ashraf 2011. Yield and chemical composition of citrus essential oils as affected by drying retreatment peels. Intern. Food Res. J., 18(4): 1275-1282.

14. Karamaouna. F., A. Kimbaris, A. Michaelakis, D. Papachristos, M. Polissiou, P. Papatsakona and E. Tsora 2013. Insecticidal activity of plant essential oils against the vine mealybug, Planococcus ficus. J. Insect Sci.,: 13:1-13.

15. Lopresto, C. G., F. P. Alessandro, A. C. B. Aliakbarian and P. V. Calabr 2014. A non-conventional method to extract $D$-limonene from waste lemon peels and comparison with traditional Soxhlet extraction. Separation and Purification Technology, 137: 13-20

16. Mansour, S. A., A. Z. El-Sharkawy and R. A. Amina 2004. Botanical biocides .12. Mosquitocidal activity of citrus peel oils with respect to their limonene content. Egyptian J. Nat. Toxins, 1: 111-134.

17. Mansour, S. A., E.A. El-Khrishy and H. F. Abdel-Hamid 2003. Botanical Biocides 10. Molluscicidal, cercaricidal and miracidicidal activities of some clove fruit constituents. J. Schistosom. Infect. Endem. Dis., 25: 15- 28.

18. Mansour, S. A., S. S. Messeha and M .S. Hamed 1996. Botanical Biocides. 1. Toxicity of some plant extracts to mosquito larvae and mosquito fish in laboratory. Proc. $3^{\text {rd }}$ Cong. Toxicol. Dev. Count., Cairo, Egypt (19-23 Nov., 1995), 3: 369-380.

19. Mohan, S. and P.G. Fields 2002. A simple technique to assess compounds that are repellent or attractive to stored product insects. J. Stored Products Res. 38: 23-31.

20. Papachristos, D. P., A. C. Kimbaris, N.T. Papadopoulos and M.G. Polissiou 2009. Toxicity of citrus essential oils against Ceratitis capitata (Diptera: Tephritidae) larvae. Ann. Appl. Biol. 155: 381-389.

21. Wang, J. L., Y. Li and C. L. Lei 2009. Evaluation of monoterpenes for the control of Tribolium castaneum (Herbst) and Sitophilus zeamaise Motschulsky- Natural Products Research, 23:1080-1088. 


\title{
التأثير السمي والطارد لزيوت قثور الموالح ضد البق الاقيقي \\ Icerya seychellarum (Weswod)
}

\author{
سامي سيد البذوي \\ مركز البحوث الزراعية- معهد بحوث وقاية النباتات - 7 شارع نادي الصيد- الدقي- الجيزة
}

يهذف هذا البحث إلي دراسة الثأثير السام والطارد للزيوت العطرية المستخلصة من قشتور

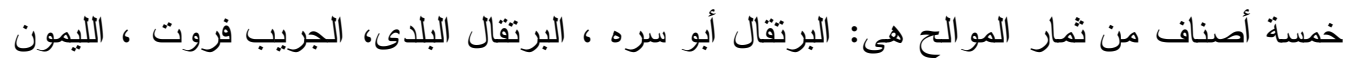

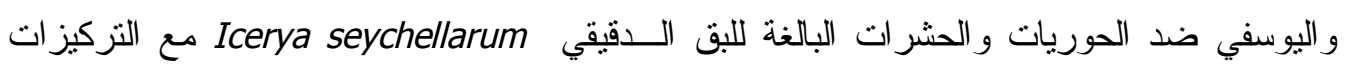
المستخدمة (1000، 5000، 10000 جزء من من مليون)، وأيضا إختبار فعالية تركيز 1.

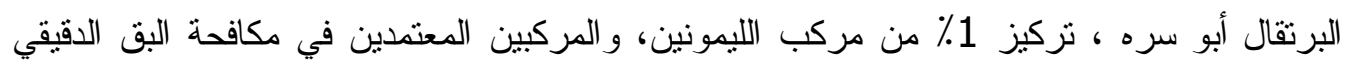

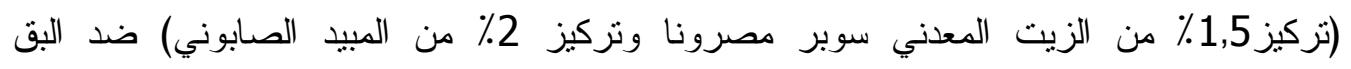
الــقيقي. وقد أظهرت النتائج أن زيت قشر ثمرة البرتقال أبو سره كان أثند الزيوت سمية للحوربات

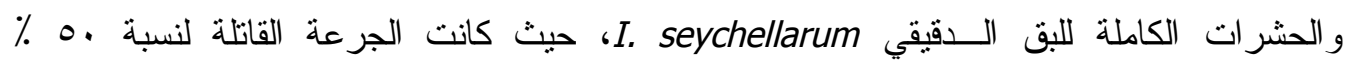

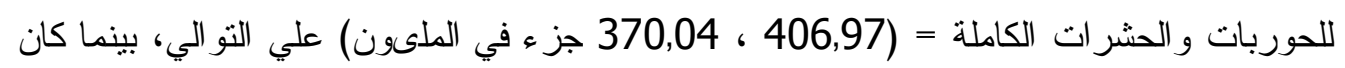

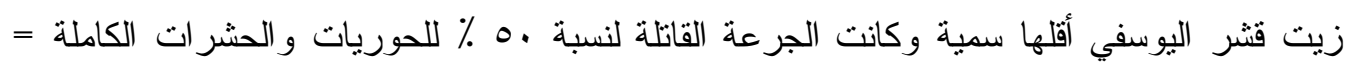

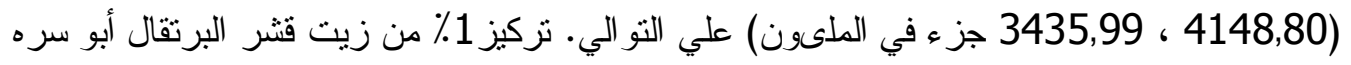

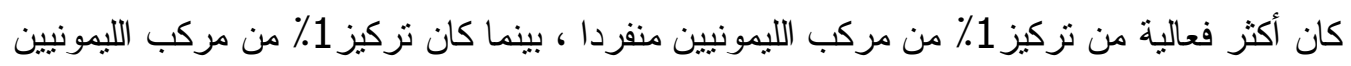

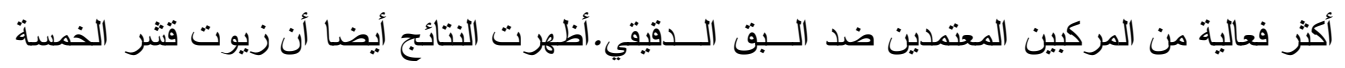

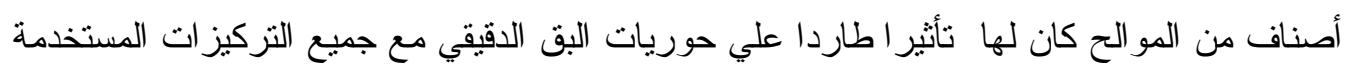

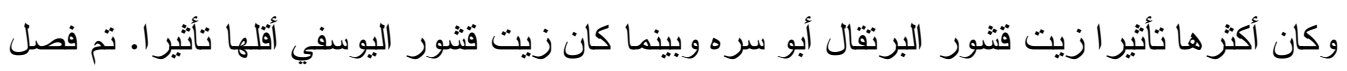

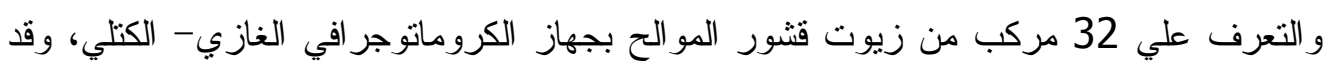

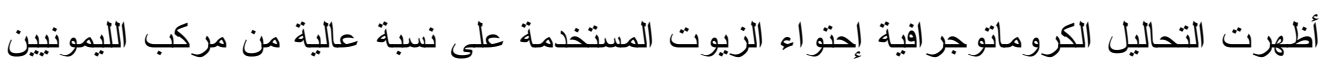
تر اوحت ما بين 67,50\%- 1,20٪.

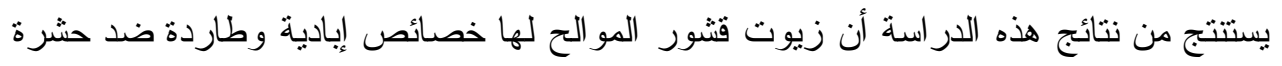

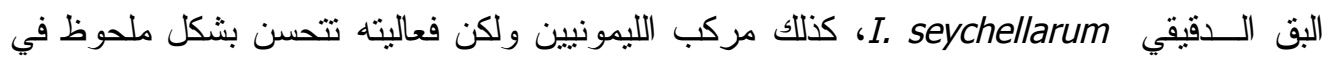

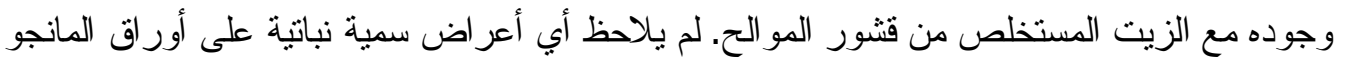

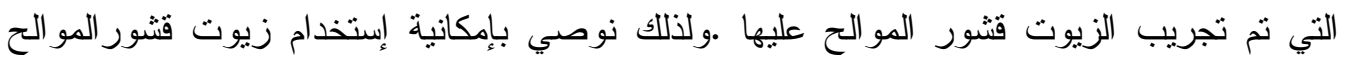

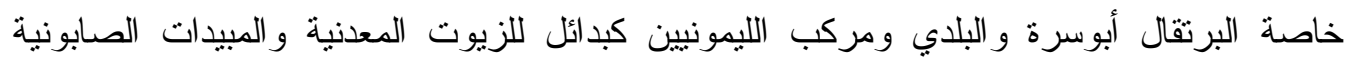

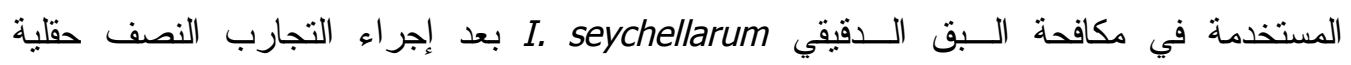
و الحقلية. 